\title{
A new species of the characid genus Hollandichthys Eigenmann from coastal rivers of southern Brazil (Teleostei: Characiformes) with a discussion on the diagnosis of the genus
}

\author{
Vinicius A. Bertaco ${ }^{1}$ and Luiz R. Malabarba ${ }^{2}$
}

Hollandichthys taramandahy, new species, is described from the rio Tramandaí, rio Mampituba, and rio Araranguá basins, coastal drainages of Rio Grande do Sul and Santa Catarina States, Brazil. The new species is distinguished from H. multifasciatus, the single recognized species of the genus, by the presence of a small black spot covering the base of median caudal-fin rays, by the lower number of dorsal and ventral procurrent caudal-fin rays, by the absence of a black spot located along anterior half of adipose-fin, and by the absence of humeral spot in specimens larger than $60 \mathrm{~mm}$ of standard length. Comments about the geographic distribution and diagnosis are provided for the genus.

Hollandichthys taramandahy, espécie nova, é descrita para as bacias dos rios Tramandaí, Mampituba e Araranguá, drenagens costeiras dos estados do Rio Grande do Sul e Santa Catarina, Brasil. A espécie nova distingui-se de H. multifasciatus, a única espécie reconhecida do gênero, pela presença de uma pequena mancha preta cobrindo a base dos raios medianos da nadadeira caudal, pelo menor número de raios procorrentes dorsais e ventrais da nadadeira caudal, pela ausência de uma mancha preta na metade anterior da nadadeira adiposa e pela ausência de mancha umeral em exemplares maiores de $60 \mathrm{~mm}$ de comprimento padrão. Comentários sobre a distribuição geográfica e diagnose são apresentados para o gênero.

Key words: Atlantic Forest, Lambari-listrado, Neotropical Fish, Pseudochalceus, Rachoviscus.

\section{Introduction}

The genus Hollandichthys was proposed by Eigenmann (1909: 257), and diagnosed in his identification key based on the "maxillary with teeth along its entire edge, lateral line very short, and with dark lines along the sides" [sic]. In that study, Eigenmann listed Hollandichthys multifasciatus (Eigenmann \& Norris, 1900) in the new genus and considered Pseudochalceus affinis Steindachner, 1908 and P. perstriatus Miranda-Ribeiro, 1908 as junior synonyms. After that, Eigenmann (1910: 432) designated Tetragonopterus multifasciatus Eigenmann \& Norris, 1900 as the type species of the genus, and maintained the synonyms previously proposed. Tetragonopterus multifasciatus was briefly described based on three specimens collected in Cubatão [São Paulo State], Pseudochalceus affinis was described from the rio Jaraguá in Joinvile, Santa Catarina State, and P. perstriatus from "Corregos de Iporanga" [São Paulo State]. Although proposed in 1909, only more than a decade later Eigenmann (1921) presented a brief description for the monotypic genus Hollandichthys, and redescribed the type species.

Based on the absence of any important anatomical differences among the species of Hollandichthys and Pseudochalceus Kner, Shultz (1966) considered the two genera as synonyms. Later, Géry (1972) proposed Hollandichthys as a subgenus of Pseudochalceus. Weitzman et al. (1986) revalidated Hollandichthys considering the differences between those genera presented by Géry (1972) and their distributions (coastal Atlantic drainages of southern and southeastern Brazil for Hollandichthys and coastal Pacific drainages of Colombia and Ecuador for Pseudochalceus). Further phylogenetic studies with different inference tools positioned Hollandichthys in distinct characid clades. Based mostly on osteology and external morphology, Mirande (2009) proposed Hollandichthys as a

${ }^{1}$ Fundação Zoobotânica do Rio Grande do Sul, Museu de Ciências Naturais, Laboratório de Ictiologia. Av. Dr. Salvador França, 1427, 90690-000 Porto Alegre, RS, Brazil.vbertaco@gmail.com

${ }^{2}$ Universidade Federal do Rio Grande do Sul, Instituto de Biociências, Departamento de Zoologia, Laboratório de Ictiologia. Av. Bento Gonçalves, 9500, 91501-970 Porto Alegre, RS, Brazil. malabarb@ufrgs.br 
member of the group named "Bramocharax clade" including Pseudochalceus, Bramocharax Gill plus Oligosarcus Günther. However, posteriorly Mirande (2010) assigned Hollandichthys to a group named "Pseudochalceus clade" formed by Hollandichthys and Pseudochalceus and considered closely related to the Rhoadsiinae. Based on molecular data, both Javonillo et al. (2010) and Thomaz et al. (2010) hypothesized Hollandichthys as the sister-group of Rachoviscus Myers, instead of Pseudochalceus.

The unique valid species of the genus, Hollandichthys multifasciatus, was hypothesized to be a third lineage of inseminating characids with modified spermatozoa by Azevedo (2004), along with the inseminating species of the Stevardiinae and the inseminating species of the tribe Compsurini of the Cheirodontinae. Quagio-Grassiotto et al. (2012) deeply explored sperm morphology in these fishes and further supported the hypothesis of close relationships among the species of Hollandichthys and Rachoviscus based on unique characters observed in the spermiogenesis and sperm ultrastructure.

Hollandichthys was previously known from coastal river basins between Rio de Janeiro and Santa Catarina States and from the upper rio Tietê, São Paulo State. Bertaco (2003) extended the southern limit of the genus to coastal rivers from northern of Rio Grande do Sul State, distribution reiterated by subsequent authors (Lima et al., 2003, 2007; Reis et al., 2003; Abilhoa et al., 2009).

Based on a comparison of several geographically isolated populations of Hollandichthys along all the geographic distribution of the genus conducted by the senior author, a new species was revealed and is described herein from the small tributaries of rio Tramandaí, rio Mampituba and rio Araranguá basins, southern Brazil. Further evidences of close relationships of Hollandichthys and Rachoviscus are discussed and a new diagnosis is provided for the genus.

\section{Material and Methods}

Counts and measurements taken following Fink \& Weitzman (1974), except for the number of scale rows below the lateral line counted from the scale row ventral to lateral line to the scale row nearest to the origin of first pelvic-fin ray. Counts of vertebrae, supraneurals, gill rakers on the first arch, teeth, and procurrent caudal-fin rays were taken from cleared and stained specimens (c\&s) prepared according to Taylor \& Van Dyke (1985). Vertebral counts included the four vertebrae of the Weberian apparatus, and the terminal centrum was counted as a single element. Procurrent caudal-fin-ray counts were also taken in some alcohol preserved specimens after the removal of the musculature with a scalpel. Lower and upper jaws of c\&s specimen were prepared for SEM (scanning electronic microscopy) by drying in acetone followed by gold metallization.
Measurements were taken point to point with a caliper on the left side of specimens. Measurements are expressed as percents of standard length (SL) except for subunits of the head, which are recorded as percents of head length (HL). Sex of adult specimens of Hollandichthys was recognized by visual examination of their gonads, anal-fin profile and/or by the presence or absence of bony hooks in fin rays. Values for the holotype are indicated by an asterisk.

Specimens examined belong to the following institutions: ANSP, Academy of Natural Sciences of Drexel University, Philadelphia; CAS, California Academy of Sciences, San Francisco; FMNH, Field Museum of Natural History, Chicago; ICNMHN, Instituto de Ciencias Naturales, Museo de Historia Natural, Bogotá; MCN, Museu de Ciências Naturais, Fundação Zoobotânica do Rio Grande do Sul, Porto Alegre; MCP, Museu de Ciências e Tecnologia, Pontifícia Universidade Católica do Rio Grande do Sul, Porto Alegre; MHNCI, Museu de História Natural Capão da Imbuia, Curitiba; MHNG, Muséum d'histoire naturelle de la Ville de Genève, Genève; MNRJ, Museu Nacional, Rio de Janeiro; MZUSP, Museu de Zoologia, Universidade de São Paulo, São Paulo; NMW, Naturistorisches Museum, Vienna; UFRGS, Departamento de Zoologia, Universidade Federal do Rio Grande do Sul, Porto Alegre; and USNM, National Museum of Natural History, Smithsonian Institution, Washington D.C.

We designated six paragenetypes (sensu Chakrabarty, 2010), including one of the vouchers previously listed as Hollandichthys multifasciatus by Thomaz et al. (2010; UFRGS 11793) that is also included in our paratypes list for H. taramandahy. COI sequences for the remaining five paragenetypes (MCP 26969) were taken by A. T. Thomaz (unpubl. data). Methods for DNA extraction and sequencing of three mitochondrial genes, 16S, cytochrome c oxidase subunit I (COI) and the NADH dehydrogenase 2 (ND2), and two nuclear genes, the nuclear gene seven in absentia (Sia) and the intron 5 of the a-tropomyosin gene (Trop) given for the paragenetypes are explained by Thomaz et al. (2010).

\section{Results}

\section{Hollandichthys taramandahy, new species Figs. 1-6}

Hollandichthys multifasciatus (non Eigenmann \& Norris, 1900). -Reis et al., 2003: 125 (endangered species in Rio Grande do Sul State, Brazil). -Thomaz et al., 2010: 1349 (in part): Table 1 (vouchers UFRGS 11792, UFRGS 11793) [see discussion below]. -Malabarba et al., 2013: 39 (short diagnosis, distribution and habitat).

Holotype. MCP 30000, 85.8 mm SL, male, Brazil, Rio Grande do Sul, Maquiné, Barra do Ouro locality, tributary of rio do Ouro, rio Tramandaí system, 29³5'18”S 50¹7’35”W, 25 Jan 2001, L. R. Malabarba, V. A. Bertaco, J. A. Anza \& T. Hasper. 


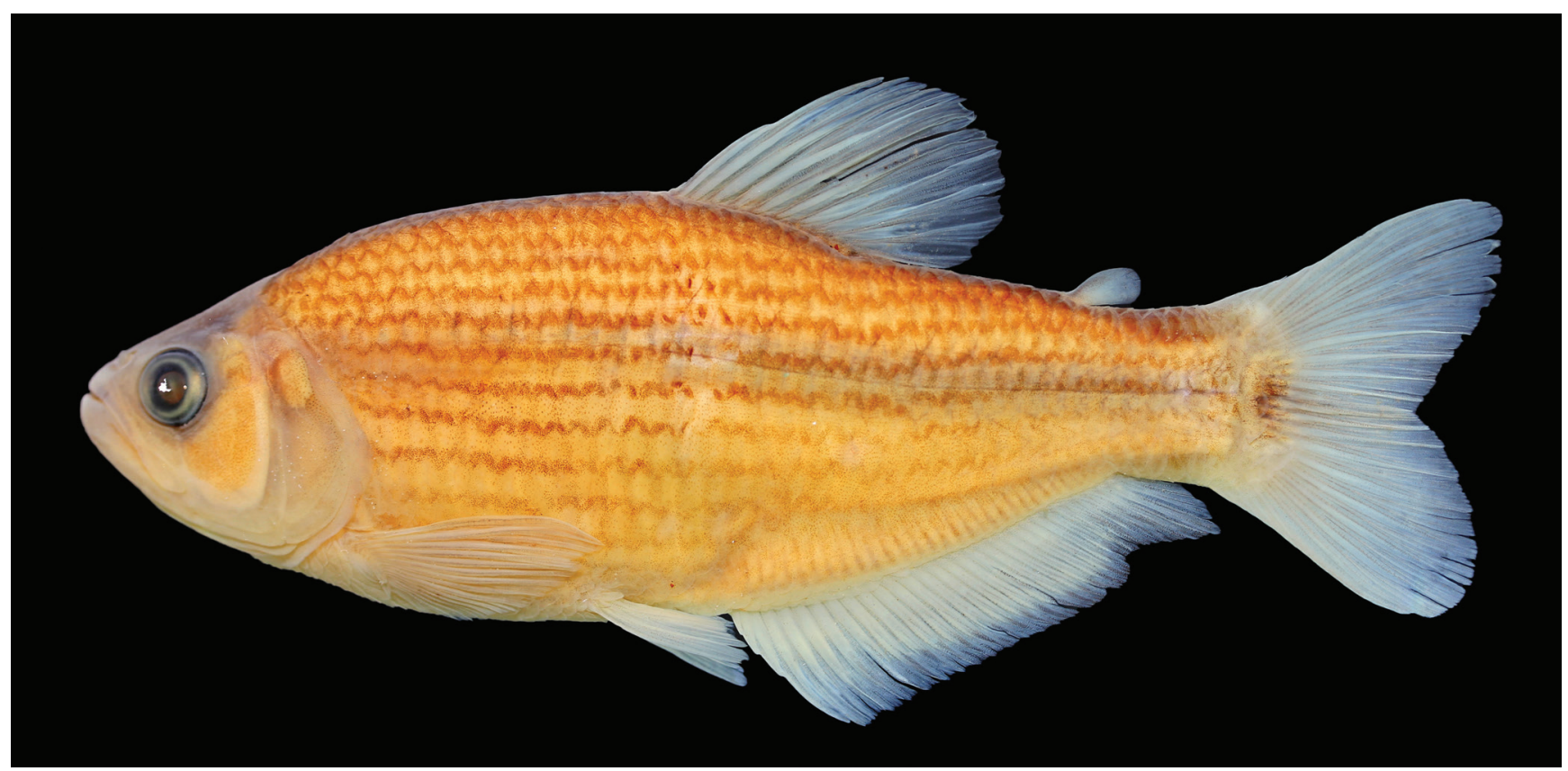

Fig. 1. Hollandichthys taramandahy, MCP 30000, holotype, male, $85.8 \mathrm{~mm}$ SL, tributary of rio do Ouro, Barra do Ouro, Maquiné, Rio Grande do Sul, Brazil.

Paratypes. Brazil, Rio Grande do Sul, Maquiné, rio Tramandaí system, rio Maquiné drainage: MCP 26969, 15, 32.6-85.8 mm SL, collected with holotype. MCN 19693, 5, 43.4-75.5 mm SL, lateral puddle of arroio Encantado, 29³5'31'S 50¹4'10”W, 12 Dec 2012, V. A. Bertaco, M. A. Azevedo \& C. L. Castilho. MCP 24621, 13 (3 c\&s), 38.6-87.8 mm SL, same locality of holotype, 31 Aug 1999, F. G. Becker, T. Finkler \& M. Vassiliou. MCP 25273, 18 (3 c\&s), 40.4-85.8 mm SL, same locality of holotype, 9 Dec 1999, F. G. Becker, V. A. Bertaco \& P. Colombo. MCP 25416, 8, 36.8-69.5 mm SL, arroio Encantado, 29³6’28”'S 50¹2'15”W, 14 Nov 1999, F. G. Becker, P. Colombo \& A. Brandt. MCP 25417, 1, 63.4 mm SL, arroio Pinheiro, 29³8'22'S 50¹3'31'W, 15 Nov 1999, F. G. Becker, P. Colombo \& A. Brandt. UFRGS 11793, 8, 47.9-88.2 mm SL, same locality of holotype, 14 Sep 2008, A. T. Thomaz, G. N. Mendes, J. F. dos Santos \& J. M. Wingert. Itati, rio Três Forquilhas drainage: MCP 29244, 15 (2 c\&s), 12.5-63.9 mm SL, creek tributary of arroio da Barra, 29²5'36"S 50¹0'44”'W, 25 Mar 2002, V. A. Bertaco \& J. F. P. da Silva. UFRGS 16513, 13 (plus tissue samples), 37.0-64.0 mm SL, lateral puddle of arroio Bananeiras, near the mouth of arroio da Barra, 29²5'36”S 50¹0’44”W, 6 Jun 2012, L. R. Malabarba, J. F. dos Santos, L. G. Artioli \& P. Carvalho Neto. Santa Catarina, Praia Grande, rio Mampituba drainage: MCP 23625, 3, 35.7-78.5 mm SL, 21 Jul 1999, E. H. L. Pereira, R. E. Reis \& J. F. P. da Silva; MCP 29241 , 9, 29.4-45.6 mm SL, MCP 29242, 12 (2 c\&s), 22.8-58.1 mm SL, arroio Molha Coco, 29¹0'13"S 4958'49”W, 25 Mar 2002, V. A. Bertaco \& J. F. P. da Silva. MCP 29243, 4 (1 c\&s), 37.1-71.9 $\mathrm{mm}$ SL, rio Mampituba, Praia Grande, 2915'13"S 5007'03”W, 25 Mar 2002, V. A. Bertaco \& J. F. P. da Silva. UFRGS 11792, 8, 49.2-62.2 mm SL (includes the voucher TEC841B, 57.4 mm SL,
GenBank Accession Numbers: SIA HM562824, Trop HM562798, 16S HM562736, COI HM562851 and ND2 HM562882; listed as H. multifasciatus by Thomaz et al., 2010), lateral puddle of rio Mampituba, 29¹5'10”'S 507’00'W, 14 Sep 2008, A. T. Thomaz, G. Neves, J. Ferrer \& J. Wingert. Rio Araranguá drainage: MCN 19802, 18, 23.0-55.5 mm SL, rio Serrinha, tributary of rio São Bento, rio Mãe Luzia basin, Treviso, ca. $28^{\circ} 27^{\prime} \mathrm{S} 49^{\circ} 30^{\prime} \mathrm{W}$, Mar 2013, C. Feltrin. UFRGS 11791, 4, 35.3-82.8 mm SL, stream at Serra da Rocinha, Timbé do Sul, 2847'27'’S 4955'44”W, 13 Sep 2008, A. T. Thomaz, G. Neves, J. Ferrer \& J. Wingert.

Paragenetype. GenBank Accession Numbers: from voucher (TEC842 E, $57.3 \mathrm{~mm} \mathrm{SL}$ ) on lot UFRGS 11793, Sia HM562823; Trop HM562799; 16S HM562735; COI HM562852, ND2 HM562883 (from Thomaz et al., 2010: Table 1); from voucher MCP 26969/38, COI JF836373; MCP 26969/39, COI JF836374; MCP 26969/40, COI JF836375; MCP 26969/41, COI JF836376; MCP 26969/42, COI JF836377.

Diagnosis. Hollandichthys taramandahy can be diagnosed from $H$. multifasciatus by the presence of a small, vertically expanded black spot at base of median caudal-fin rays (Figs. 1-4), clearly visible after fixation in formalin or alcohol (vs. absence of a black spot on caudal fin, Fig. 7); adipose fin without distinctive marks ( $v s$. anterior portion of adipose fin black, Fig. 7); absence of humeral spot on specimens larger than $60.0 \mathrm{~mm} \mathrm{SL} \mathrm{(} v s$. humeral spot always present, Fig. 7; two black humeral spots present on small specimens of both species). Furthermore, H. taramandahy can be distinguished from $H$. multifasciatus by the number 
of dorsal procurrent caudal-fin rays $(8-11$, mode $=10, \mathrm{n}=$ 20 , vs. $10-15$, mode $=12, \mathrm{n}=72$, respectively) and ventral procurrent caudal-fin rays $(7-8$, mode $=8, \mathrm{n}=20, v s .9-12$, mode $=10, n=72$, respectively), and by the shorter length of the penultimate branched anal-fin ray in adult males $(9.0-12.3$ in SL, mean $=10.5$ vs. $11.1-20.8$ in $\mathrm{SL}$, mean $=$ 14.9 , respectively).
Description. Morphometric data summarized in Table 1. Body compressed and elongate; greatest body depth anterior to dorsal-fin origin. Dorsal head profile gently concave. Snout slightly pointed. Dorsal body profile slightly convex from supraoccipital bone to base of last dorsal-fin ray and straight from this point to adipose-fin origin. Ventral body profile convex from anterior tip of lower jaw to pelvic-fin

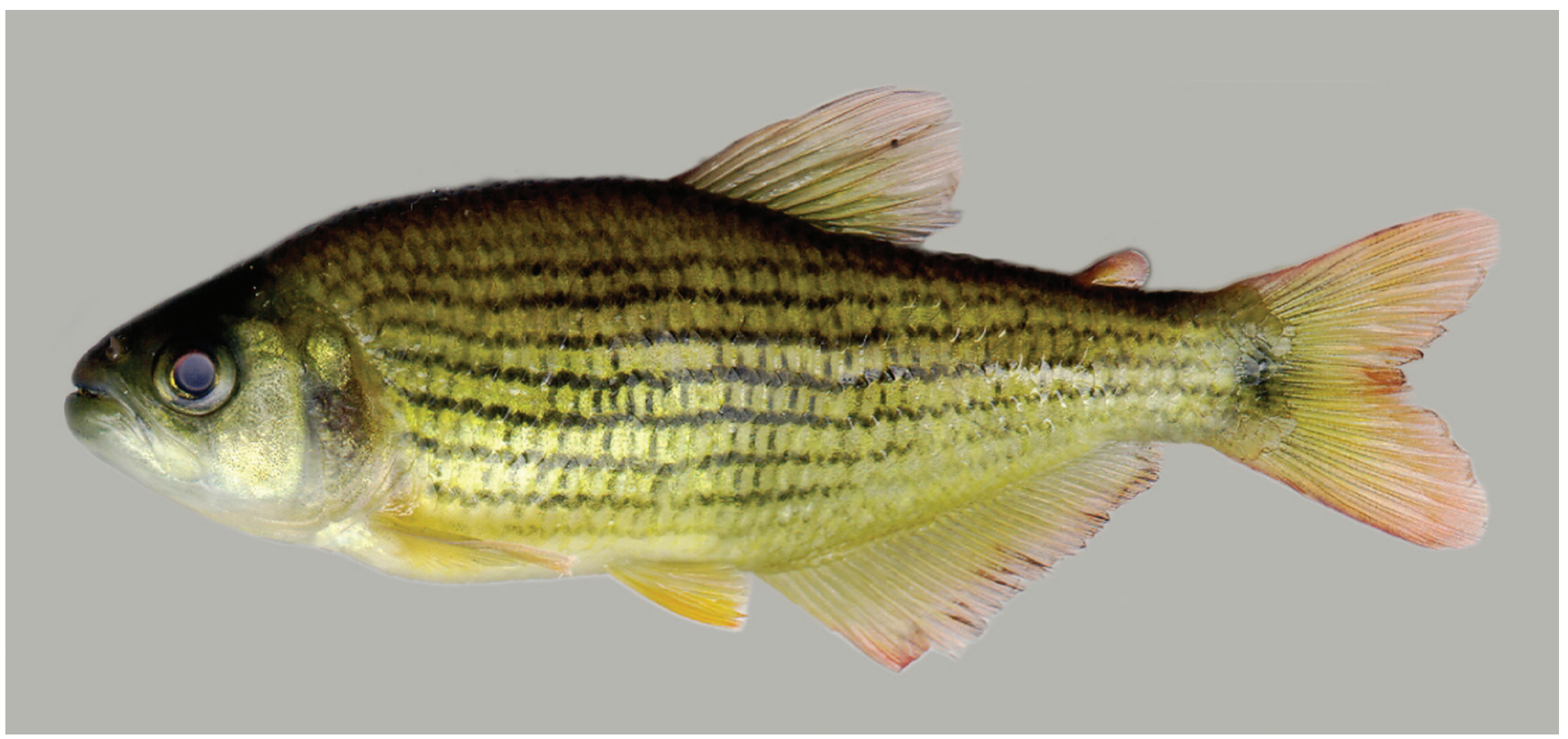

Fig. 2. Hollandichthys taramandahy, MCP 29243, paratype, female, $71.9 \mathrm{~mm}$ SL, rio Mampituba, Praia Grande, Santa Catarina, Brazil. Photo taken just after fixation in formalin.

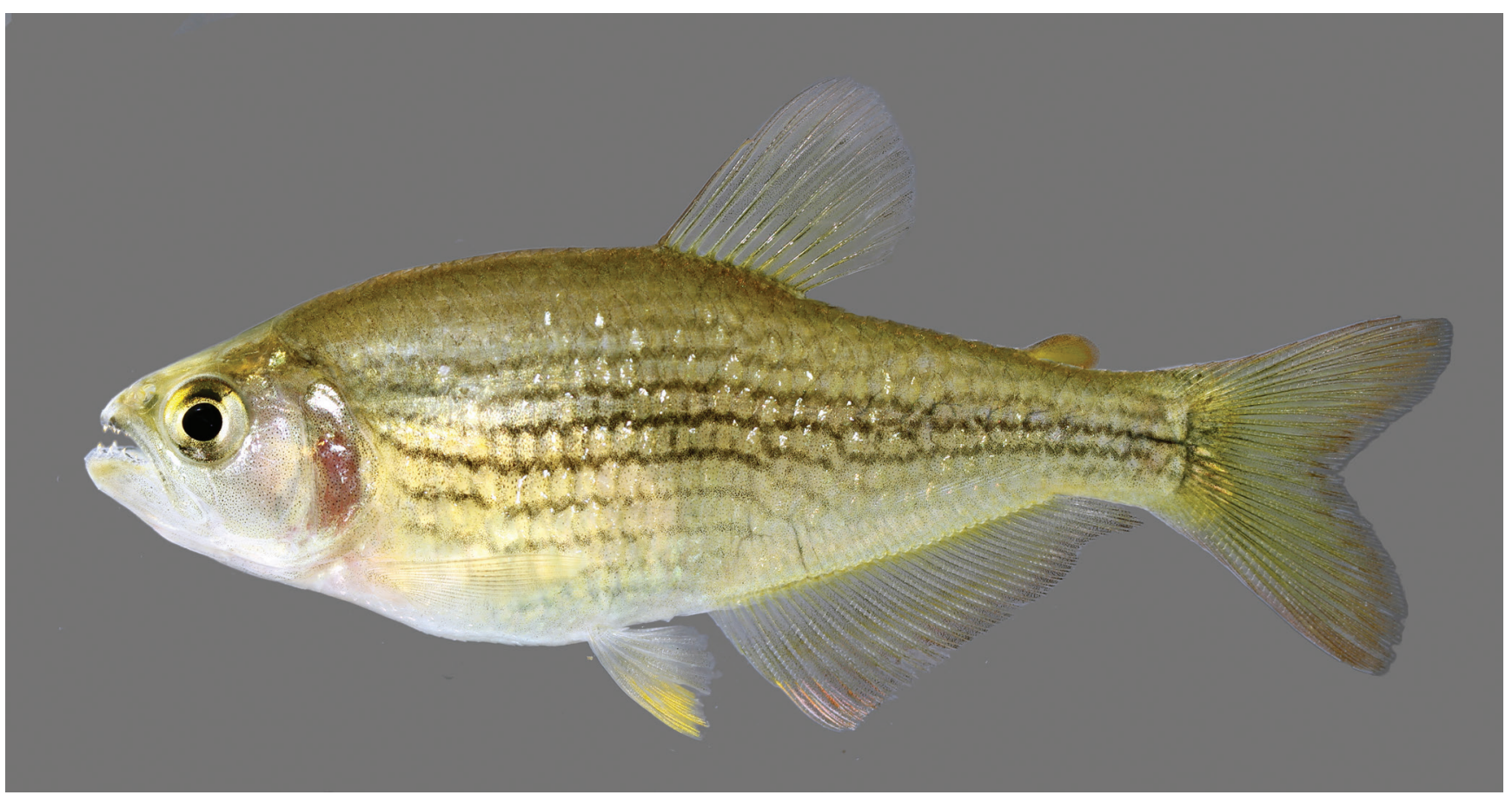

Fig. 3. Hollandichthys taramandahy, UFRGS 16513, paratype, male, $64.0 \mathrm{~mm} \mathrm{SL}$, lateral puddle of arroio Bananeiras, near the mouth of arroio da Barra, Itati, Rio Grande do Sul, Brasil. Live specimen. 


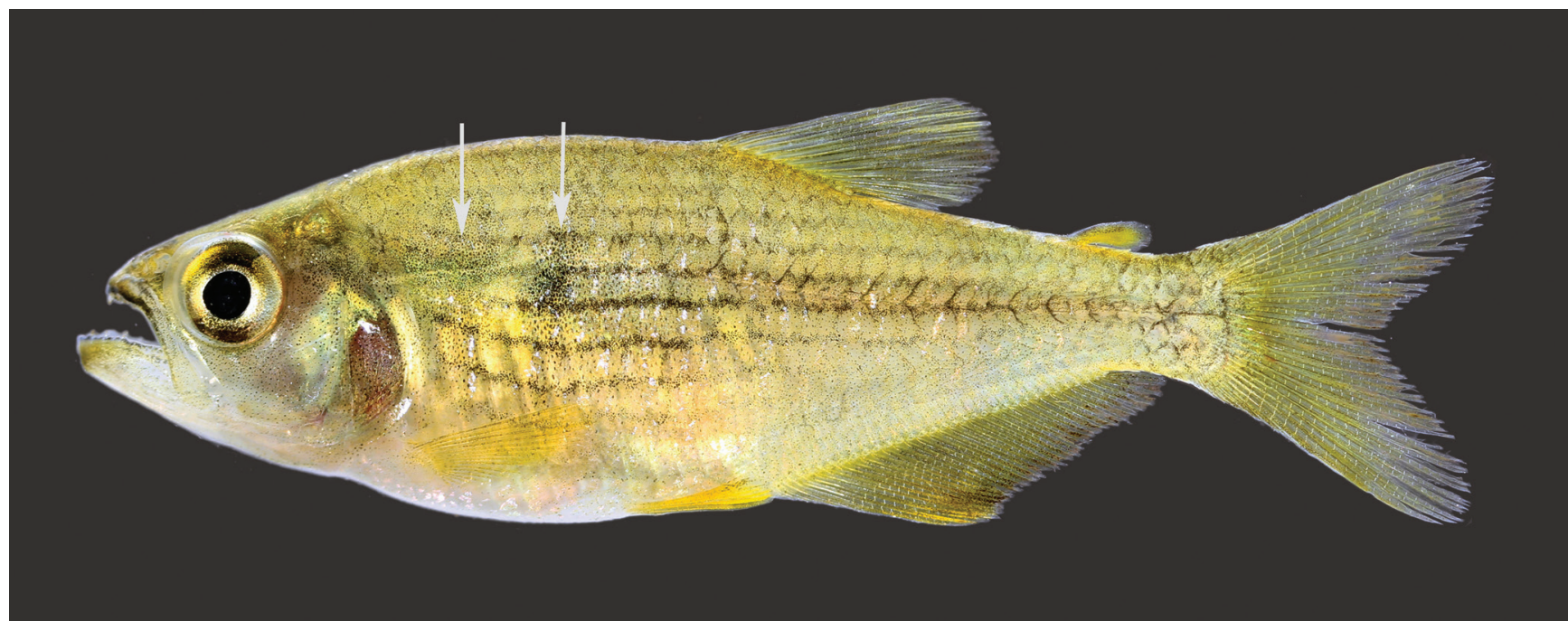

Fig. 4. Hollandichthys taramandahy, UFRGS 16513, paratype, $37.0 \mathrm{~mm} \mathrm{SL}$, lateral puddle of arroio Bananeiras, near the mouth of arroio da Barra, Itati, Rio Grande do Sul, Brasil. Live specimen. First (anterior) and second (posterior) humeral spots indicate with arrows.

origin and straight from the latter point to anal-fin origin. Body profile along anal-fin base posterodorsally slanted. Caudal peduncle nearly straight to slightly concave along dorsal and ventral margins.

Mouth slightly superior. Lower jaw protruding anteriorly with respect to upper jaw. Maxilla extending posteriorly to vertical through center of eye, and aligned at angle of approximately 45 degrees to longitudinal body axis.

Premaxilla with two tooth rows; outer row with two or three*, rarely four, tricuspid teeth with central cusp longest; inner row with five teeth, with three to five cusps (fourth or fifth cusp diminute); central cusp three or four times longer and broader than other cusps; symphyseal tooth much longer than remaining teeth. Maxilla with 13-17 (usually 13-14, $\left.15^{*}\right)$ tricuspid teeth, with central cusp longer. Four or five anteriormost dentary teeth large, with three to four cusps (fourth cusp diminute), followed by one medium sized tricuspid tooth, and 7-12 teeth with two to three cusps, rarely conical; central cusp in all teeth three or four times longer and broader than other cusps. All cusp tips slightly curved towards oral cavity (Fig. 5).

Dorsal-fin rays $\mathrm{ii}, 9 *(\mathrm{n}=51)$; first unbranched ray approximately one-half the length of second ray. Dorsal-fin origin posterior to middle of SL and posterior to vertical through pelvic-fin origin. Dorsal-fin profile slightly rounded. Unbranched and anterior 3 to 4 dorsal-fin rays bearing large posterior flap along posterolateral borders, more developed in specimens larger than $60 \mathrm{~mm} \mathrm{SL}$, extending along entire length of first unbranched ray and proximal midlength of second unbranched and anterior branched rays. Adipose fin located approximately at vertical through insertion of $20^{\text {th }}$ $22^{\text {th }}$ anal-fin rays.

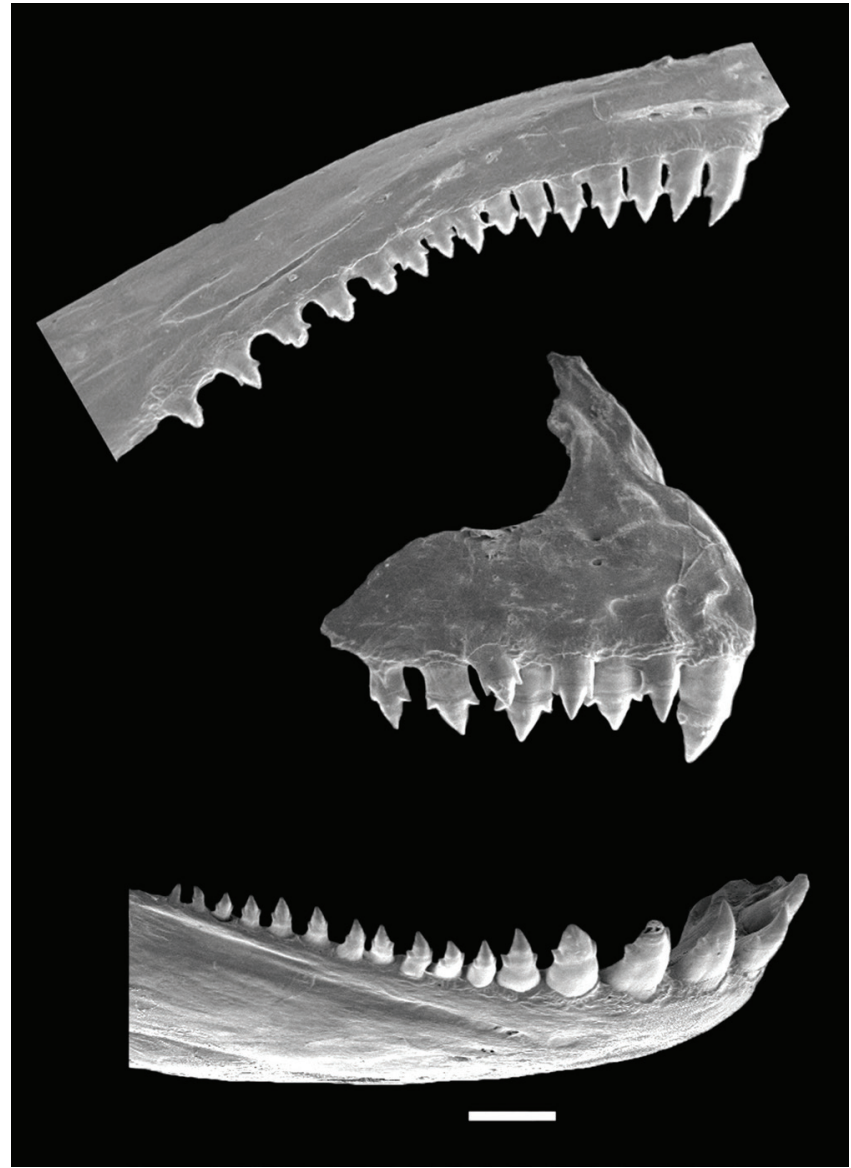

Fig. 5. Hollandichthys taramandahy, MCP 24621, paratype, $78.1 \mathrm{~mm}$ SL. Scanning electronic micrograph of the premaxilla (middle) and of toothed portion of maxilla (top) and dentary (bottom), right side. Scale bar $=1 \mathrm{~mm}$. 


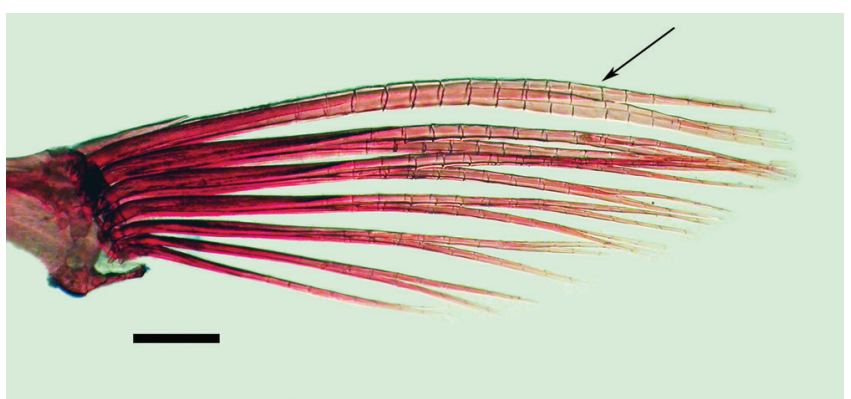

Fig. 6. Hollandichthys taramandahy, MCP 24621, paratype, female, $64.7 \mathrm{~mm} \mathrm{SL}$, c\&s. Ventral view of the left pelvic fin. Note the anteriormost lateral branched ray (arrow). Scale bar $=1 \mathrm{~mm}$.

Anal-fin rays iii-v,27-30 (iii,28*; rarely 26, mode $=29$, $\mathrm{n}=51$ ). First unbranched ray usually only apparent in c\&s specimens. Anal-fin origin at vertical through base of third to fourth branched dorsal-fin rays. Unbranched and anterior two to three branched anal-fin rays bearing a large posterior flap along their posterolateral borders, more developed in larger specimens of both sexes, extending along entire length of anterior unbranched rays and proximal midlength of last unbranched and anterior branched rays.

Pectoral-fin rays i,11-14* (mode $=13, \mathrm{n}=51)$. Pelvic-fin rays $6, i^{*}$ (rarely $5, \mathrm{i}, \mathrm{n}=51$ ). First pelvic-fin ray unbranched in specimens smaller than $35.0 \mathrm{~mm}$ SL, and branched in larger specimens (Fig. 6). Pelvic-fin origin anterior to vertical through dorsal-fin origin. Caudal fin forked, lobes similar in size, i, 17, i* principal rays $(n=50$, one specimen with $i, 16, i)$. Caudal-fin lobes slightly rounded. Presence of irregular small scales at base of lower caudal-fin lobe, extending posteriorly to vertical through one-half the length of middle caudal-fin rays. Dorsal procurrent caudal-fin rays $8-11($ mode $=10, \mathrm{n}=20)$. Ventral procurrent caudal-fin rays 7-8 (mode $=8, \mathrm{n}=20)$.

Scales cycloid, moderately large; some body scales on flanks with posterior margin truncate or concave. Lateral line incomplete, perforated scales $6 *-9(\operatorname{mode}=8, \mathrm{n}=50)$. Longitudinal series of scales including lateral-line scales 37 40 , rarely $41(39 *$; mode $=38, \mathrm{n}=50)$. Scale rows between dorsal-fin origin and lateral line $6-7^{*}(\operatorname{mode}=7, \mathrm{n}=51)$; scale rows between lateral line and pelvic-fin origin 5-6* $(\operatorname{mode}=6, \mathrm{n}=51)$. Predorsal scales 12-16 $\left(14^{*}\right.$; mode $=$ $14, n=45)$, arranged in irregular series. Scale rows around caudal peduncle $14 *-16($ mode $=14, \mathrm{n}=50)$. Axillary scale on pelvic-fin origin extending posteriorly covering one scale. Single series of 8-15 scales on scale sheath along anal-fin base $\left(11^{*}, n=47\right)$, extending to base of sixth to twentieth branched rays.

Precaudal vertebrae 16-18; caudal vertebrae 20-21; total vertebrae 36-39, usually $37(\mathrm{n}=6)$. Supraneurals 6-7 $(\mathrm{n}=6)$. Gill-rakers of first gill arch 7 on upper limb and 10-11 on lower $\operatorname{limb}(n=6)$.
Table 1. Morphometric data of holotype (H, MCP 30000) and paratypes of Hollandichthys taramandahy, new species, from the rio Tramandaí system (MCP 24621, 25273, 25416, 25417, $26969,29244)$ and rio Mampituba drainage (MCP 23625, 29241, $29242,29243)$. The range includes the holotype $(\mathrm{H}) . \mathrm{m}=$ males; $\mathrm{f}=$ females; $\mathrm{N}=$ number of specimens; $\mathrm{SD}=$ standard deviation.

\begin{tabular}{lccccc}
\hline & $\mathrm{H}$ & $\mathrm{N}$ & Range & Mean & $\mathrm{SD}$ \\
\hline Standard length (mm) & 85.8 & 50 & $36.8-87.8$ & 61.5 & - \\
& Percents of standard length & & \\
Predorsal distance & 54.9 & 50 & $52.6-62.6$ & 56.2 & 2.0 \\
Prepelvic distance & 48.2 & 50 & $44.2-54.1$ & 49.5 & 1.7 \\
Prepectoral distance & 28.0 & 50 & $26.4-32.5$ & 29.0 & 1.2 \\
Preanal distance & 58.9 & 50 & $55.6-68.5$ & 61.4 & 2.4 \\
Depth at dorsal-fin origin & 35.4 & 50 & $31.7-39.4$ & 35.6 & 1.6 \\
Caudal peduncle depth & 13.5 & 50 & $10.7-14.3$ & 12.3 & 0.7 \\
Caudal peduncle length & 9.3 & 50 & $7.2-12.2$ & 9.7 & 1.7 \\
Anal-fin base & 35.1 & 50 & $32.1-38.3$ & 34.7 & 1.2 \\
Dorsal-fin length & 28.2 & 50 & $25.3-29.5$ & 27.8 & 1.0 \\
Pelvic-fin length (m) & 14.8 & 30 & $14.3-17.3$ & 15.5 & 0.8 \\
Pelvic-fin length (f) & - & 20 & $14.0-15.8$ & 14.8 & 0.5 \\
Pectoral-fin length (m) & 22.3 & 30 & $19.0-23.6$ & 21.8 & 1.2 \\
Pectoral-fin length (f) & - & 20 & $18.6-21.6$ & 20.2 & 0.7 \\
Head length & 26.9 & 50 & $26.3-32.7$ & 29.3 & 1.4 \\
& Percents of head length & & \\
Snout length & 29.0 & 50 & $24.4-33.3$ & 28.4 & 2.5 \\
Upper jaw length & 53.8 & 50 & $48.9-56.9$ & 54.0 & 1.5 \\
Orbital diameter & 25.7 & 50 & $25.1-31.2$ & 27.6 & 1.5 \\
Interorbital width & 34.2 & 50 & $27.0-36.5$ & 32.3 & 2.0 \\
\hline
\end{tabular}

Color in alcohol. Ground color dark yellow in dorsal region of body and head, gradually lighter on sides. Dark brown longitudinal lines usually forming a zigzag pattern between longitudinal rows of scales, except immediately above anal-fin base; more conspicuous along the longitudinal axis of the body, more visible in specimens larger than $50.0 \mathrm{~mm}$ SL (Fig. 1). Small black chromatophores scattered over rays of all fins. Adipose fin without distinctive marks, except for the anterodorsal border smoothly light gray pigmented. Small black spot vertically expanded at base of median caudal-fin rays (Figs. 1-2). Specimens measuring 42.0-50.0 mm SL with one or two faint and vertically elongate humeral spots. Color pattern of specimens smaller than $41.0 \mathrm{~mm}$ SL similar to that of large specimens, but always with two black vertically elongate humeral spots; anterior diffuse, located over first to fourth perforated lateral-line scales and sometimes extending over horizontal series of scales just above lateral line. Second humeral spot darker, located over seventh to eighth perforated lateral-line scales and sometimes extending over horizontal series of scales just above lateral line. Specimens larger than $60.0 \mathrm{~mm}$ SL without humeral spots (Figs. 1-2). Specimens up to $45 \mathrm{~mm} \mathrm{SL}$ with chevron-shaped striae posteriorly diverging from longitudinal line, following miosepta. The remaining fins with dispersed dark 
cromatophores. Anal fin of specimens larger than $50 \mathrm{~mm}$ SL with one longitudinal black band along its middle-distal portion.

Color in life. Overall coloration light golden to greenish, except for the lateral and ventral portions of head and belly with ground coloration white. Anterior portion of dentary and dorsal portion of snout yellow. Iris dark brown above and below pupil and bright yellow anterodorsally. Tip of pelvic fin and adipose fin yellow; tip of the anterior lobe of the anal fin reddish, caudal fin light orange to reddish and dorsal and pelvic fins hyaline in a young male (Fig. 3). All fins yellow in an unsexed young specimen with $41 \mathrm{~mm}$ SL (Fig. 4). Specimens smaller than $41.0 \mathrm{~mm}$ SL with two black vertically elongate humeral spots, first spot diffuse and second spot more conspicuous (Fig. 4). Caudal fin spot hardly discernible in live specimens (Figs. 3 and 4). Dark brown longitudinal lines more conspicuous along the longitudinal axis of the body. Specimens up to $41 \mathrm{~mm}$ SL (Fig. 4) with chevron-shaped striae posteriorly diverging from longitudinal line, following myosepta.

Sexual dimorphism. Males of H. taramandahy are easily recognized by the presence of bony hooks on branched rays of anal and pelvic fins. Anal-fin rays of sexually mature males bear one pair of small, elongate, retrorse bony hooks along posterolateral border of each segment of lepidotrichia, along third through $27^{\text {th }}$ (usually fourth to $23^{\text {th }}$ ) branched rays; hooks more numerous along seventh through $20^{\text {th }}$ branched rays, rarely present on $27^{\text {th }}$ ray. Hooks usually located along posteriormost branch and distal half to two thirds of each ray. Pelvic fin of males usually bearing one retrorse bony hook per segment of lepidotrichia along ventromedial border of third to fifth branched rays.

Anal-fin profile nearly straight along most of its ventral border in males, except for a concavity in the posterior portion,

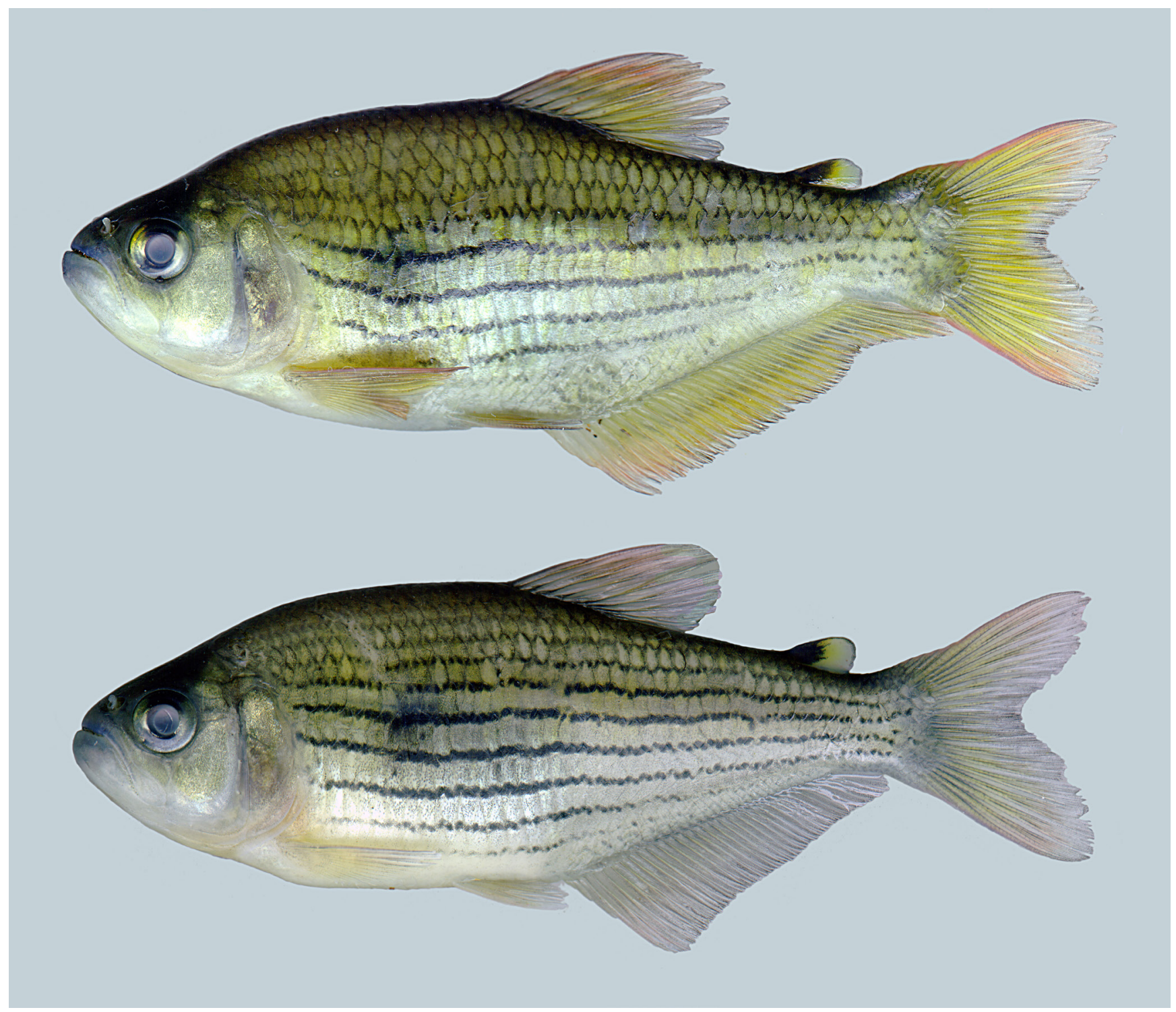

Fig. 7. Hollandichthys multifasciatus, MCP 30559, male, above, $85.8 \mathrm{~mm} \mathrm{SL}$, female, below, $73.0 \mathrm{~mm}$ SL, tributary of rio Quilombo, Quilombo, Cubatão, São Paulo State. 


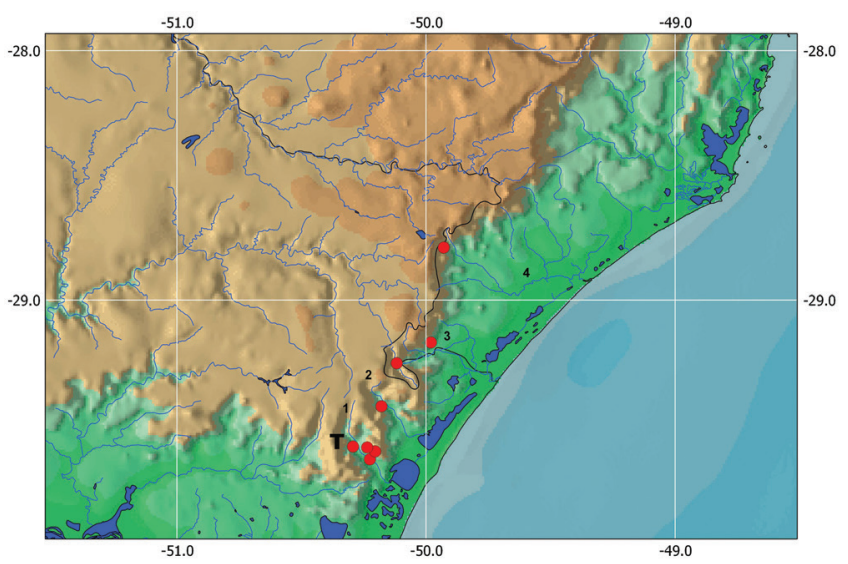

Fig. 8. Distribution of Hollandichthys taramandahy, new species (red circles), in the rio Tramandaí system (1- rio Maquiné, 2- rio Três Forquilhas), and rio Mampituba (3) and rio Araranguá (4) drainages. Some symbols represent more than one locality or lot of specimens. $\mathrm{T}=$ type locality.

corresponding approximately to the position of the $20^{\text {th }}$ to $25^{\text {th }}$ rays; three or four posteriormost branched anal-fin rays longer than other rays, forming a conspicuous anal-fin lobe; penultimate ray longest (Figs. 1 and 3). Anal-fin profile nearly straight in all its extension in females (Fig. 2).

Males and females also differ in proportions of the pectoral- and pelvic-fin lengths (Table 1). Caudal peduncle depth slightly wider in males than females, and procurrent caudal-fin rays more developed in males. Gill glands (Burns \& Weitzman, 1996) were not observed macroscopically on first gill arch in either males or females.

Distribution. Hollandichthys taramandahy in known from smaller tributaries of the rio Maquiné and rio Três Forquilhas, rio Tramandaí system, Rio Grande do Sul and from rio Mampituba and Araranguá drainages, Santa Catarina, Brazil. Rio Maquiné represents the meridional limit of distribution of the genus (Fig. 8).

Etymology. The species name, taramandahy, is in reference to the drainage of the type locality. In Tupi Guarani language, Taramandahy (=Tramandaí) means winding river, or where is about to harvest (related to fish harvesting). A noun in apposition.

Ecological notes. All specimens were caught in lateral puddles of rivers and very small tributaries with shallow and lentic black waters, with mud and leaf on the bottom, and very dense riparian vegetation, similar to what was observed by Sabino \& Castro (1990) for H. multifasciatus in an Atlantic Forest stream in Ubatuba, São Paulo State, southeastern Brazil. The larger specimens (70.0-80.0 $\mathrm{mm} \mathrm{SL})$ were found isolated and small specimens $(30.0-40.0 \mathrm{~mm}$ SL) were captured in groups of 3 to 6 fishes, as also observed by Sabino \& Castro (1990) for H. multifasciatus. Although extensive collection efforts have been applied in sampling fishes along

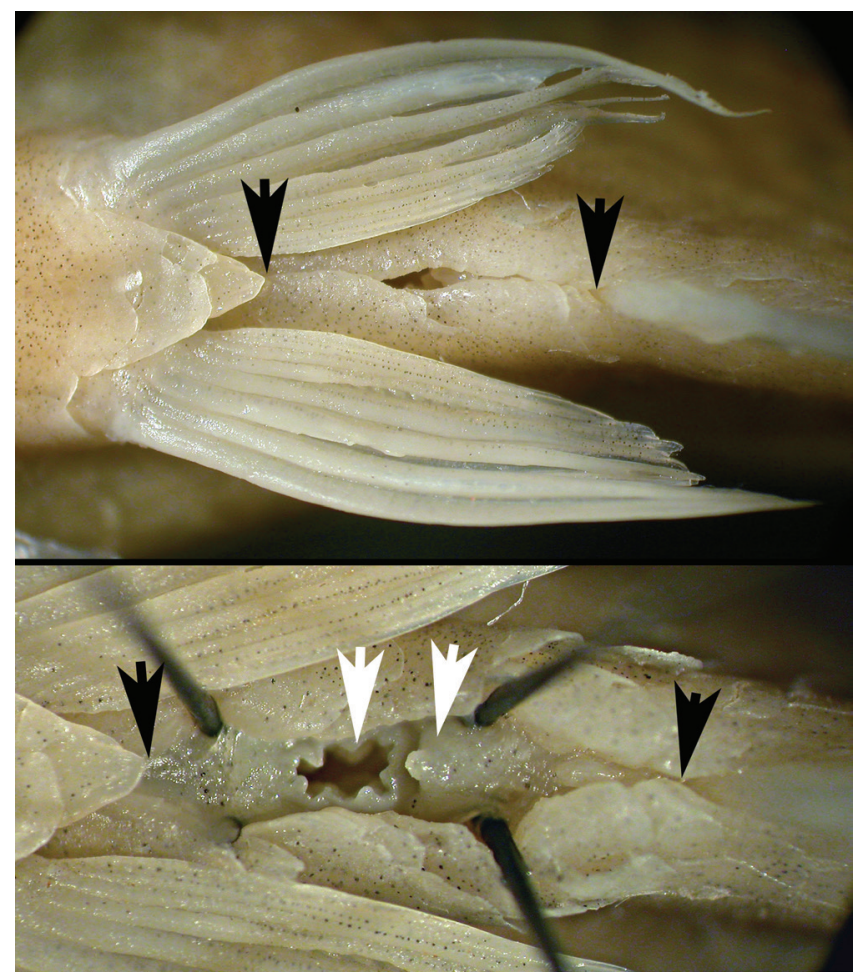

Fig. 9. Hollandichthys taramandahy, MCP 25273, paratype, male, $79.4 \mathrm{~mm}$ SL. Ventral body cavity between the pelvic and anal fins. Above: fissure visible ventrally (black arrows indicate its anterior and posterior limits). Below: body cavity opened with pins, showing the anus (left white arrow) and urogenital papilla (right white arrow).

the last 30 years in the rio Maquiné, rio Três Forquilhas and rio Mampituba drainages, $H$. taramandahy was never caught in the main river itself, characterized by having clear and lotic water, stones on the substrate, and few riparian vegetation. Stomach contents of three specimens (MCP 24621) prepared for clearing and staining consisted of spiders, ants, beetles, and insect parts. Other species collected along with $H$. taramandahy were Astyanax laticeps, Astyanax sp., Cyanocharax itaimbe, Cyphocharax voga, Gymnotus sp., Hyphessobrycon luetkenii, Mimagoniates rheocharis, Phalloceros spiloura, and Steindachnerina biornata.

Conservation note. Hollandichthys taramandahy was listed as endangered species in the state of Rio Grande do Sul, Brazil (Reis et al., 2003), but named as H. multifasciatus (popular name Lambari-listrado). The species is threatened due to its very limited distribution range, in areas subject to high level of anthropogenic disturbances, e.g., deforestation of stream margins.

\section{Discussion}

Javonillo et al. (2010), Thomaz et al. (2010), and QuagioGrassiotto et al. (2012) presented strong support to the hypothesis that Hollandichthys is more closely related to 
Rachoviscus than to Pseudochalceus or any other characid genera included in those analyses. This hypothesis was advanced in an unpublished thesis by Quevedo (2006), based mostly on osteology and general morphology. It is hard to argue in favor of the old hypothesis (Schultz, 1966; Géry, 1972) of a close relationship of Hollandichthys to Pseudochalceus, reinforced by Mirande (2009, 2010), due to the absence of Rachoviscus species in Mirande's analyses and therefore the lack of a testable hypothesis of relationships among the three genera in those two papers. Hollandichthys is very similar to Pseudochalceus in the color pattern and in the almost fully toothed maxilla, but as pointed out by Thomaz et al. (2010) this similarity seems to represent convergence or shared plesiomorphic traits.

The clade formed by Hollandichthys and Rachoviscus can be diagnosed from other characiforms by a unique type of spermiogenesis and by the presence of unique long and spiraling mitochondria in the midpiece of the spermatozoa of the species of both genera (Quagio-Grassiotto et al., 2012: fig.4). The last character is shared with $H$. taramandahy, as observed in transmission electronic microscopy (TEM) preparation of the testis of one of the paratypes of MCP 29244 (M. A. Azevedo, unpubl.). A third character that supports a close relationship between the species of the two genera is the presence of a body cavity ventrally between the pelvic and anal fins in males and females that houses internally the anus and urogenital opening (Fig. 9). This arrangement may play some role in the sperm transference from males to females (Quevedo, 2006). This is not observed in Pseudochalceus or any other Characidae, but is shared by Hollandichthys multifasciatus, H. taramandahy, and Rachoviscus species and thus is considered herein a putative synapomorphy of the two genera.

Hollandichthys multifasciatus and H. taramandahy share an unique sexually dimorphic character among characids represented by the posterior region of the anal fin of males with a concavity in the distal margin, formed by reduction in length of branched anal-fin rays 20-25 and elongation of the posterior ones (Figs. 1, 3 and 7). This is not observed among other species of characid fishes and is hypothesized herein as a putative synapomorphy for Hollandichthys species that diagnoses the genus from Rachoviscus. Another character shared by both species of Hollandichthys is the branched anteriormost ray of the pelvic fin (Fig. 6). The first pelvic-fin ray is unbranched in almost all characids (except in the genera Glandulocauda and Mimagoniates of the subfamily Stevardiinae) and further diagnoses Hollandichthys from Rachoviscus. The co-occurrence of the first pelvic-fin ray branched in Hollandichthys and some stevardiines seems to be homoplastic, since Glandulocauda and Mimagoniates are deeply nested with Clade A characids (Malabarba \& Weitzman, 2003; Javonillo et al., 2010; Mirande, 2010; Oliveira et al., 2011) that excludes Hollandichthys and Rachoviscus. Although Hollandichthys possesses small scales at base of the lower caudal-fin lobe, extending posteriorly to vertical through half-length of middle caudal-fin rays, no glandular tissue of granular appearance are observed in mature males, as described for the Glandulocaudinae and Stevardiinae sensu Menezes \& Weitzman (2009).

The presence of dark zigzag longitudinal stripes between longitudinal rows of scales on the lateral surfaces of body further diagnoses Hollandichthys from Rachoviscus, but is homoplastically shared with Astyanax lineatus (Perugia, 1891), A. kullanderi Costa (1995), A. superbus Myers (1942), Bario steindachneri (Eigenmann, 1893), Ectrepopterus uruguayensis (Fowler, 1943), Hyphessobrycon hexastichos Bertaco \& Carvalho (2005), Markiana nigripinnis (Perugia, 1891), Moenkhausia agnesae Géry (1965), M. latissima (Eigenmann, 1908), M. simulata (Eigenmann, 1924), Pseudochalceus lineatus Kner (1863), and Tetragonopterus rarus (Zarske, Géry \& Isbrücker, 2004). All these species, however, lack the synapomorphies described above defining the clade Hollandichthys + Rachoviscus or the aforementioned synapomorphies for Hollandichthys species. The high number of maxillary teeth (10 to 23) present in Hollandichthys species further distinguishes them from all these species $(0$ to 6), except from Ectrepopterus uruguayensis (6 to 11) and Pseudochalceus lineatus (10 to 21). The color pattern of Ectrepopterus uruguayensis is variable, but some individuals larger than $35.0 \mathrm{~mm}$ SL have the dorsal and ventral borders of scales dark brown forming a wavy striped pattern between longitudinal rows of scales (Malabarba et al., 2012), similar to that of Hollandichthys multifasciatus and H. taramandahy. This similarity apparently induced some researchers (and aquarists) to identify $H$. multifasciatus from drainages of Uruguay as recorded by Lang (2001) and Nion et al. (2002). Recent collecting efforts in the tributaries of the río Uruguay (río Cuareim, río Salto and río Negro basins), río Santa Lucía and arroyo Pandó (coastal drainages), in the Uruguay country, revealed the occurrence of E. uruguayensis in these basins (Malabarba et al., 2012), but not of H. multifasciatus or H. taramandahy. Probably the records of Hollandichthys to Uruguay basins are due to misidentification.

Monophyly of Hollandichthys was demonstrated by Thomaz et al. (2010: fig. 1), who found two well supported sister clades among fourteen samples of Hollandichthys in a Bayesian analysis with Sia, Trop, 16S, COI and ND2 genes. Hollandichthys taramandahy is part of the southern Hollandichthys clade of their cladogram, represented by two lots that cluster together from the rio Maquiné and rio Mampituba (UFRGS 11793 and UFRGS 11792, respectively). The remaining lots from the southern clade (MCP 38333, Florianópolis Island; UFRGS 10579, São Francisco do Sul; MHNCI uncat, Paranaguá) do not belong to Hollandichthys taramandahy. In all these specimens the caudal peduncle spot is absent. 
Currently, Hollandichthys multifasciatus has two junior synonyms, Pseudochalceus affinis (rio Jaraguá, tributary of the rio Itapocu, coastal drainage of Santa Catarina State) and $P$. perstriatus (córregos de Iporanga, rio Ribeira de Iguape basin, São Paulo State). Morphological (Bertaco, 2003), molecular (Thomaz et al., 2010) and karyotypic variability (Balen et al., 2013) among the populations currently identified as Hollandichthys multifasciatus, however, suggests the existence of a species complex under this taxon name, and the validity of these nominal species is under review by the authors. None of these names, however, are applicable for $H$. taramandahy. The type series of Pseudochalceus affinis and examined specimens from the type locality of $P$. perstriatus (rio Ribeira de Iguape basin) lack the small black spot covering the base of the median caudal-fin rays that is diagnostic for $H$. taramandahy and have more dorsal and ventral procurrent caudal-fin rays (10-13, mode $=12$, and 8-11, mode $=10, \mathrm{n}=5$, in the type series of P. affinis, and 11-15, mode $=12$, and 9-12, mode $=11, \mathrm{n}=46$, in specimens from the rio Ribeira de Iguape basin) than $H$. taramandahy $(8-11$, mode $=10$, and 7-8, mode $=8, \mathrm{n}=20)$. Furthermore, specimens from the rio Ribeira de Iguape basin possess a small black spot located on the proximal portion of the adipose-fin and a black humeral spot in specimens larger than $60.0 \mathrm{~mm}$ SL (both absent in H. taramandahy).

The species of the genus Hollandichthys inhabit coastal rivers and marine islands from northern Rio Grande do Sul State to southern Rio de Janeiro State, and the upper rio Tietê in the upper rio Paraná drainage, included in the area of the Atlantic Rainforest biome. Such a distribution pattern strongly corroborates the recognition of a large area of endemism comprising the coastal drainages of south and southeastern Brazil, including the headwaters of rio Tietê. This is similar or largely congruent with the distribution of species of the genera Deuterodon Eigenmann (Lucena \& Lucena, 1992, 2002), Kronichthys Miranda-Ribeiro (Ferraris, 2007), Mimagoniates Regan (Menezes et al., 2008; Menezes \& Weitzman, 2009), Spintherobolus Eigenmann (Weitzman \& Malabarba, 1999), Scleromystax Günther (Britto \& Reis, 2005), and Pareiorhaphis Miranda-Ribeiro (Pereira \& Reis, 2002; Pereira, 2005).

Hollandichthys taramandahy inhabits small tributaries from the rio Maquiné and rio Três Forquilhas (rio Tramandaí system), and Mampituba and Araranguá river basins. Malabarba \& Isaia (1992) identified the region comprising the rio Maquiné, rio Três Forquilhas, and rio Mampituba as an area of endemism of fish species, later extended to the next northern drainage of the rio Araranguá by evidence presented by Reis \& Schaefer (1999). Other taxa that show a geographic distribution similar to $H$. taramandahy and that support the recognition of an area of endemism comprising the rio Maquiné, rio Três Forquilhas, rio Mampituba, and rio Araranguá are the characids Cyanocharax itaimbe Malabarba
\& Weitzman, Deuterodon stigmaturus (Gomes) (Lucena \& Lucena, 1992, 2002), Mimagoniates rheocharis Menezes \& Weitzman, and Odontostoechus lethostigmus Gomes (Malabarba, 1998), the loricariid genus Epactionotus Reis \& Schaefer (1998), and two monophyletic groups of loricariids of the genus Pareiorhaphis (Pereira \& Reis, 2002). This distribution pattern is partially congruent with the freshwater ecoregion Tramandaí-Mampituba recently recognized by Abell et al. (2008).

Comparative material. Brazil: Astyanax lineatus: MCP 15617, 5 (1 c\&s), 42.8-88.8 mm SL, stream at road between Cuiabá and Cáceres, Cáceres, Mato Grosso. Hollandichthys multifasciatus: CAS 61483, 2 of 3 syntypes, 31.4-66.8 mm SL, Cubatão, São Paulo. FMNH 54313, 3, 29.5-79.4 mm SL, rio Ribeira de Iguape basin, Iporanga, São Paulo. MCP 28734, 4, 54.3-74.0 mm SL, tributary of rio Araçatuba, Garopaba, Santa Catarina. MCP 28737, 35 (3 c\&s), 34.4-88.1 mm SL, stream Córrego Grande, Florianópolis, Santa Catarina. MCP 30557, 9, 44.6-62.4 mm SL, tributary of rio Serra Negra, Guaraqueçaba, Paraná. MCP 30559, 22, 14.3-85.8 mm SL, tributary of rio Quilombo, Santos, São Paulo. MNRJ 10952, 9, 49.7$94.5 \mathrm{~mm}$ SL, rio Itinguçú at Itacuruçá, Mangaratiba, Rio de Janeiro. MZUSP 28848, 13, 19.8-46.2 mm SL, tributary of rio Grande, Santo André, São Paulo. MZUSP 62884, 18 (1 c\&s), 16.8-79.6 mm SL, stream in track of Cachoeira, Estação Ecológica Juréia-Itatins, Iguape, São Paulo. UFRGS 11771, 5, 34.4-55.4 mm SL (includes the voucher TEC 888A; Thomaz et al., 2010), stream in Bertioga, São Paulo. UFRGS 11773, 5, 37.7-97.8 mm SL (includes the voucher TEC 897C; Thomaz et al., 2010), stream Taquarubu, São Sebastião, São Paulo. UFRGS 11776, 13, 45.8-86.9 mm SL (includes the voucher TEC 909D; Thomaz et al., 2010), stream Toca do Boi, Parati, Rio de Janeiro. UFRGS 11782, 2, 37.5-46.2 mm SL (includes the voucher TEC 739A; Thomaz et al., 2010), stream on the road between Iguape and Icapara, Iguape, São Paulo. UFRGS 11784, 15, 37.3-61.4 mm SL (includes the voucher TEC 722H; Thomaz et al., 2010), locality of Guaraú, Peruíbe, São Paulo. UFRGS 11785, 7, 35.9-59.6 mm SL (includes the voucher TEC 820E; Thomaz et al., 2010), Cubatão, São Paulo. UFRGS 11787, 19, 36.3-64.8 $\mathrm{mm}$ SL (includes the voucher TEC 827C; Thomaz et al., 2010), Paranapiacaba, São Paulo. UFRGS 11788, 2, 26.4-61.7 mm SL (includes the voucher TEC 859A; Thomaz et al., 2010), rio Guaecá, São Sebastião, São Paulo. Nematocharax venustus: MCP 17977, 49 (2 c\&s), 15.1-31.6 mm SL, rio Jequitinhonha, Itaobim, Minas Gerais. Pseudochalceus affinis: NMW 56736, 2 syntypes, 78.0-83.2 mm SL, NMW 56737, 3 syntypes, 70.0-82.5 mm SL, rio Jaraguá, Joinvile, Santa Catarina. Rachoviscus crassiceps: MCP 37986, 15, 14.5-22.1 mm SL, MZUSP 18564, 8 (1 c\&s), 18.6-23.4 mm SL, praia de Brejatuba, Guaratuba, Paraná. Rachoviscus graciliceps: UFRGS 11028, 16, 25.5-42.5 mm SL, stream $6.5 \mathrm{~km} \mathrm{~N}$ of Prado, Prado, Bahia. Colombia: Pseudochalceus longianalis: ANSP 140067, 1 paratype, $34.3 \mathrm{~mm} \mathrm{SL}$, rio Guiza tributary of rio Mira. ICNMHN 2338, 5, 39.4-59.6 mm SL, stream Angostura, tributary 
of rio Mira, Narino. Pseudochalceus bohlkei: MCP 31914, 2 c\&s, 36.7-39.0 mm SL, MHNG 2536.96, 22, 20.6-48.7 mm SL, tributary of rio Mira, border with Colombia. Ecuador: USNM 287746, 4 (1 c\&s), 36.8-58.4 mm SL, Esmeraldas. Pseudochalceus kyburzi: USNM 324462, 9 of 11 (4 c\&s), 37.8-64.8 mm SL (aquarium trade). Pseudochalceus lineatus: ANSP 75906, 1, $80.2 \mathrm{~mm} \mathrm{SL}$, rio Toachi near Santo Domingo of Los Colorados, Pichincha. USNM 287747, 5 (1 c\&s), 24.6-43.7 mm SL, rio Chirape tributary of rio Guayllabama, R. Esmeraldos de Paraiso. Uruguay: Ectrepopterus uruguayensis: UFRGS 7985, 53, 29.8-44.3 mm SL, arroyo Guaviyú on road 3 , tributary of río Uruguay, Artigas.

\section{Acknowledgments}

We are grateful to Mark Sabaj Pérez and John Lundberg (ANSP), David Catania (CAS), Barry Chernoff(FMNH), Ivan Mojica (ICNMHN), Claude Weber (MHNG), Paulo Buckup and Marcelo Britto (MNRJ), Osvaldo Oyakawa (MZUSP), Helmut Wellendorf (NMW), Susan Jewett (USNM) for selection and loan of specimens; to Centro de Microscopia Eletrônica (UFRGS) for the SEM preparations; to Paulo H. Lucinda (UFT) by suggestions and discussions; and to Andréa T. Thomaz that provided the DNA sequences for the paragenetypes. Andréa T. Thomaz, Fernando G. Becker, Fernando R. Carvalho, José F. P. da Silva, Juan A. Anza, Juliano F. dos Santos, Marco A. Azevedo, Pablo C. Lehmann, and Verônica C. Baumbach helped in field collecting. The senior author thanks to Conselho Nacional de Desenvolvimento Científico e Tecnológico - CNPq for the student fellowship and the Museu de Ciências e Tecnologia da PUCRS for the support. Thanks to PRONEX (Project "Conhecimento, conservação e utilização racional da diversidade da fauna de peixes do Brasil") and CNPq (Procs. 464545/00-5, 479412/2008-1) by financial support for collecting expedition. VAB was financed by a postdoctoral fellowship from CNPq (Proc. 150042/20094), and FAPERGS (Proc. 0903014), and LRM is supported by CNPq (Proc. 300705/2010-7).

\section{Literature Cited}

Abell, R., M. L. Thieme, C. Revenga, M. Bryer, M. Kottelat, N. Bogutskaya, B. Coad, N. Mandrak, S. Contreras Balderas, W. Bussing, M. L. J. Stiassny, P. Skelton, G. R. Allen, P. Unmack, A. Naseka, R. Ng, N. Sindorf, J. Robertson, E. Armijo, J. V. Higgins, T. J. Heibel, E. Wikramanayake, D. Olson, H. L. López, R. E. Reis, J. G. Lundberg, M. H. Sabaj-Pérez \& P. Petry. 2008. Freshwater Ecoregions of the World: A new map of biogeographic units for freshwater biodiversity conservation. BioScience, 58: 403-414.

Abilhoa, V., H. Bornatowski \& G. Otto. 2009. Temporal and ontogenetic variations in feeding habits of Hollandichthys multifasciatus (Teleostei: Characidae) in coastal Atlantic rainforest streams, southern Brazil. Neotropical Ichthyology, 7: 415-420.

Azevedo, M. A. 2004. Análise comparada de caracteres reprodutivos em três linhagens de Characidae (Teleostei: Ostariophysi) com inseminação. Unpublished Ph.D. Dissertation, Universidade Federal do Rio Grande do Sul, Porto Alegre, 238p.

Balen, R. E., R. B. Noleto, M. R. Vicari, R. F. Artoni \& M. M. Cestari. 2013. Comparative cytogenetics among populations of Hollandichthys multifasciatus (Teleostei: Characidae). Zoological Science, 30: 105-109.

Bertaco, V.A. 2003. Taxonomia e filogenia do gênero Hollandichthys Eigenmann, 1909 (Teleostei: Characidae) do Sul e Sudeste do Brasil. Unpublished M.Sc. Dissertation, Pontifícia Universidade Católica do Rio Grande do Sul, Porto Alegre, 159p.

Britto, M. R. \& R. E. Reis. 2005. A new Scleromystax species (Siluriformes: Callichthyidae) from coastal rivers of southern Brazil. Neotropical Ichthyology, 3: 481-488.

Burns, J. R. \& S. H. Weitzman. 1996. Novel gill-derived gland in the male swordtail characin, Corynopoma riisei (Teleostei: Characidae: Glandulocaudinae). Copeia, 1996: 627-633.

Chakrabarty, P. 2010. Genetypes: a concept to help integrate molecular phylogenetics and taxonomy. Zootaxa, 2632: 67-68.

Eigenmann, C. H. 1909. The fresh-water fishes of Patagonia and an examination of the Archiplata-Archhelenis theory. Pp. 225-374. In: Reports of the Princeton University expeditions to Patagonia, 1896-1899, 3(3). Princeton University \& Stuttgart.

Eigenmann, C. H. 1910. Catalogue of the freshwater fishes of tropical and south temperate America. Pp. 375-511. In: Reports of the Princeton University expeditions to Patagonia, 1896-1899, 3(4). Princeton University \& Stuttgart.

Eigenmann, C. H. 1921. The American Characidae. Memoirs of the Museum of Comparative Zoology, 43 (pt 3): 209-310.

Eigenmann, C. H. \& A. A. Norris. 1900. Sobre alguns peixes de São Paulo, Brasil. Revista do Museu Paulista, 4: 349-362.

Ferraris, C. J. Jr. 2007. Checklist of catfishes, recent and fossil (Osteichthyes: Siluriformes), and catalogue of siluriform primary types. Zootaxa, 1418: 1-628.

Fink, W. L. \& S. H. Weitzman. 1974. The so-called Cheirodontin fishes of Central America with descriptions of two new species (Pisces: Characidae). Smithsonian Contribution of Zoology, 172: 1-46.

Géry, J. 1972. Contribution à L'étude des poissons Characoïdes de l'Équateur. Avec une révision du genre Pseudochalceus et la description d'une nouveaux genre endémique du rio Cauca en Colombie. Acta Humboldtiana, Series Geologica, Paleontologica et Biologica, 2: 1-110.

Javonilo, R., Malabarba, L. R., S. H. Weitzman \& J. R. Burns. 2010. Relationships among major lineages of characid fishes (Teleostei: Ostariophysi: Characiformes), based on molecular sequence data. Molecular Phylogenetics and Evolution, 54: 498-511.

Lang, J. J. R. 2001. Atlas ilustrado de los peces de agua dulce del Uruguay. Rocha, PROBIDES.

Lima, F. C. T., P. A. Buckup, N. A. Menezes, C. A. S. Lucena, Z. M. S. Lucena, M. Toledo-Piza \& A. Zanata. 2007. Pp. 44-62. In: Buckup, P. A., N. A. Menezes \& M. S. Ghazzi. 2007. Catálogo das espécies de peixes de água doce do Brasil. Rio de Janeiro, Museu Nacional.

Lima, F. C. T., L. R. Malabarba, P. A. Buckup, J. F. Pezzi da Silva, R. P. Vari, A. Harold, R. Benine, O. T. Oyakawa, C. S. Pavanelli, N. A. Menezes, C. A. S. Lucena, M. C. S. L. Malabarba, Z. M. S. Lucena, R. E. Reis, F. Langeani, L. Casatti, V. A. Bertaco, C. Moreira \& P. H. F. Lucinda. 2003. Genera Incertae Sedis in Characidae. Pp. 106-169. In: Reis, R. E., S. O. Kullander \& C. J. Ferraris (Eds.). Check List of the Freshwater Fishes of South and Central America. Porto Alegre, Edipucrs. 
Lucena, C. A. S. \& Z. M. S. Lucena. 2002. Redefinição do gênero Deuterodon Eigenmann, 1907 (Ostariophysi, Characiformes, Characidae). Comunicações do Museu de Ciências e Tecnologia, Pontifícia Universidade Católica do Rio Grande do Sul, Série Zoologia, 15: 113-135.

Lucena, Z. M. S. \& C. A. S. Lucena. 1992. Revisão das espécies do gênero Deuterodon Eigenmann, 1907 dos sistemas costeiros do sul do Brasil com a descrição de quatro espécies novas (Ostariophysi, Characiformes, Characidae). Comunicações do Museu de Ciências e Tecnologia, Pontifícia Universidade Católica do Rio Grande do Sul, Série Zoologia, 5: 123-168.

Malabarba, L. R. 1998. Monophyly of the Cheirodontinae, characters and major Clades (Ostariophysi: Characidae). Pp. 199-233. In: Malabarba, L. R., R. E. Reis, R. P. Vari, Z. M. S. Lucena \& C. A. S. Lucena. (Orgs.). Phylogeny and classification of neotropical fishes. Porto Alegre, Edipucrs.

Malabarba, L. R., V. A. Bertaco, F. R. Carvalho \& T. C. Litz. 2012. Revalidation of the genus Ectrepopterus Fowler (Teleostei: Characiformes), with the redescription of its type species, $E$. uruguayensis. Zootaxa, 3204: 47-60.

Malabarba, L. R., P. Carvalho Neto, V. A. Bertaco, T. P. Carvalho, J. Ferrer \& L. G. S. Artioli. 2013. Guia de identificação dos peixes da bacia do rio Tramandaí. Porto Alegre: Via Sapiens.

Malabarba, L. R. \& E. A. Isaia. 1992. The fresh water fish fauna of the rio Tramandaí drainage, Rio Grande do Sul, Brazil, with a discussion of its historical origin. Comunicações do Museu de Ciências e Tecnologia, Pontifícia Universidade Católica do Rio Grande do Sul, Série Zoologia, 5: 197-223.

Malabarba, L. R. \& S. H. Weitzman. 2003. Description of a new genus with six new species from Southern Brazil, Uruguay and Argentina, with a discussion of a putative characid clade (Teleostei: Characiformes: Characidae). Comunicações do Museu de Ciências e Tecnologia, Pontifícia Universidade Católica do Rio Grande do Sul, Série Zoologia, Porto Alegre, 16: 67-151.

Menezes, N. A., A. C. Ribeiro, S. H. Weitzman \& R. A. Torres. 2008. Biogeography of Glandulocaudinae (Teleostei: Characiformes: Characidae) revisited: phylogenetic patterns, historical geology and genetic connectivity. Zootaxa, 1726: 33-48.

Menezes, N. A. \& S. H. Weitzman. 1990. Two new species of Mimagoniates (Teleostei: Characidae: Glandulocaudinae), their phylogeny and biogeography and a key to the glandulocaudin fishes of Brazil and Paraguay. Proceedings of the Biological Society of Washington, 103: 380-426.

Menezes, N. A. \& S. H. Weitzman. 2009. Systematics of the Neotropical fish subfamily Glandulocaudinae (Teleostei: Characiformes: Characidae). Neotropical Ichthyology, 7: 295-370.

Mirande, J. M. 2009. Weighted parsimony phylogeny of the family Characidae (Teleostei: Characiformes). Cladistics, 2: 574-613.

Mirande, J. M. 2010. Phylogeny of the family Characidae (Teleostei: Characiformes): from characters to taxonomy. Neotropical Ichthyology, 8: 385-568.

Nion, H., C. Ríos \& P. Meneses. 2002. Peces del Uruguay: lista sistemática y nombres comunes. DINARA, Montevideo, Uruguay.

Oliveira, C., G. S. Avelino, K. T. Abe, T. C. Mariguela, R. C. Benine, G. Ortí, R. P. Vari \& R. M. C. e Castro. 2011. Phylogenetic relationships within the speciose family Characidae (Teleostei: Ostariophysi: Characiformes) based on multilocus analysis and extensive ingroup sampling. BMC Evolutionary Biology, 11: 275.
Oliveira, C. L. C. de, L. R. Malabarba \& J. R. Burns. 2012. Comparative morphology of gill glands in externally fertilizing and inseminating species of cheirodontine fishes, with implications on the phylogeny of the family Characidae (Actinopterygii: Characiformes). Neotropical Ichthyology, 10: 349-360.

Pereira, E. H. L. 2005. Resurrection of Pareiorhaphis Miranda Ribeiro, 1918 (Teleostei: Siluriformes: Loricariidae), and description of a new species from the rio Iguaçu basin, Brazil. Neotropical Ichthyology, 3: 271-276.

Pereira, E. H. L. \& R. E. Reis. 2002. Revision of the loricariid genera Hemipsilichthys and Isbrueckerichthys (Teleostei: Siluriformes), with descriptions of five new species of Hemipsilichthys. Ichthyological Exploration Freshwaters, 13: 97-146.

Quagio-Grassiotto, I., L. R. Malabarba, M. A. Azevedo, J. R. Burns, C. M. Baicere-Silva \& R. Quevedo. 2012. Unique derived features in spermiogenesis and sperm morphology supporting a close relationship between the species of Hollandichthys and Rachoviscus (Characiformes: Characidae). Copeia, 2012: 609-625.

Quevedo, R. 2006. Estudo taxonômico e filogenético da subfamília Paragoniatinae Géry (Characiformes: Characidae). Unpublished Ph.D. Dissertation, Universidade Federal do Rio Grande do Sul, Porto Alegre.

Reis, R. E., Z. M. S. Lucena, C. A. Lucena \& L. R. Malabarba. 2003. Peixes. Pp. 117-164. In: Fontana, C. S., G. A. Bencke \& R. E. Reis (Eds.). Livro vermelho da fauna ameaçada de extinção no Rio Grande do Sul. Porto Alegre, Edipucrs.

Reis, R. E. \& S. A. Schaefer. 1998. New cascudinhos from Southern Brazil: Systematics, Endemism, and Relationships (Siluriformes, Loricariidae, Hypoptopomatinae). American Museum Novitates, 3254: $1-25$.

Sabino, J. \& R. M. C. Castro. 1990. Alimentação, período de atividade e distribuição espacial dos peixes de um riacho da Floresta Atlântica (Sudeste do Brasil). Revista Brasileira de Biologia, 50: 23-36.

Schultz, L. P. 1966. Pseudochalceus kyburzi, a new characid fish from Colombia. Ichthyologica, The Aquarium Journal, 37: 25-30.

Taylor, W. R. \& G. C. Van Dyke. 1985. Revised procedures for staining and clearing small fishes and other vertebrates for bone and cartilage study. Cybium, 9: 107-119.

Thomaz, A. T., L. R. Malabarba \& S. L. Bonatto. 2010. The phylogenetic placement of Hollandichthys Eigenmann 1909 (Teleostei: Characidae) and related genera. Molecular and Phylogenetics and Evolution, 57: 1347-1352.

Weitzman, S. H. \& L. R. Malabarba. 1999. Systematics of Spintherobolus (Teleostei: Characidae: Characiformes) from eastern Brazil. Ichthyological Exploration of Freshwaters, 10: $1-43$.

Weitzman, S. H., N. A. Menezes \& H. A. Britski. 1986. Nematocharax venustus, a new genus and species of fish from the rio Jequitinhonha, Minas Gerais, Brazil (Teleostei: Characidae). Proceedings of the Biological Society of Washington, 99: 335-346.

Submitted April 25, 2013 Accepted August 30, 2013 by George Mattox Published December 27,2013 